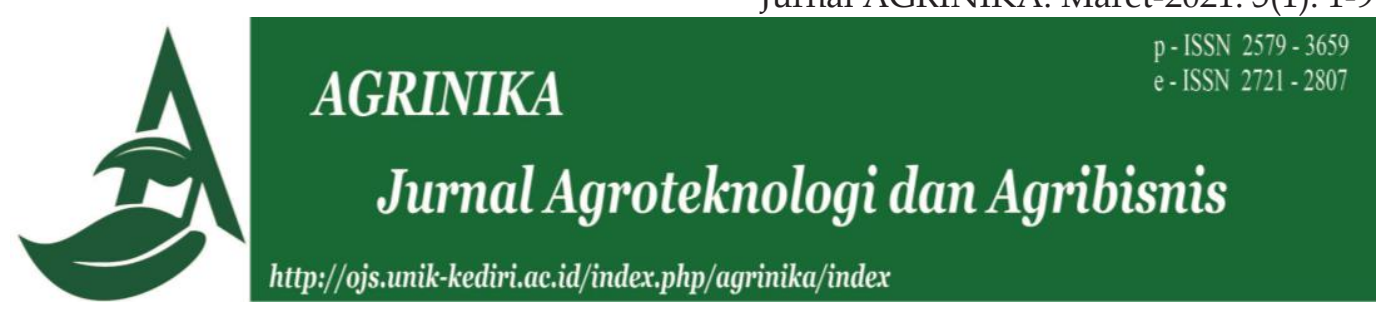

\title{
Pengaruh Penggunaan KNO3 pada Pertumbuhan Bibit Kelapa Sawit (Elaeis guineensis Jack) Fase Pre-Nursery
}

\author{
Kresna Shifa Usodri ${ }^{1 *}$ dan Bambang Utoyo ${ }^{1}$ \\ Jurusan Budidaya Tanaman Perkebunan, Politeknik Negeri Lampung \\ *Korespondensi: kresna@polinela.ac.id
}

Diterima 17 Februari 2021/ Direvisi 27 Februari 2021/ Disetujui 9 Maret 2021

\begin{abstract}
ABSTRAK
Pemenuhan bibit berkualitas dalam upaya peningkatan produktivitas kelapa sawit, dapat dilakukan dengan cara pemilihan jenis pupuk yang sesuai. Salah satu pupuk yang dapat digunakan dalam mengoptimalkan pertumbuhan bibit di pre-nursery adalah dengan menggunakan $\mathrm{KNO}_{3}$. Penelitian dilakukan dengan tujuan untuk mendapatkan konsentrasi pupuk KNO3 yang tepat dalam mengoptimalkan pertumbuhan bibit tanaman kelapa sawit pada fase pre-nursery. Penelitian dilakukan di Unit Pembibitan Kelapa Sawit, Politenik Negeri Lampung. Rancangan percobaan yang digunakan adalah perlakuan tunggal dengan lima ulangan. Perlakuan terdiri dari pupuk NPK majemuk anjuran (P1), pupuk KNO3 konsentrasi 1\% (P2), pupuk KNO3 konsentrasi 2\% (P3), pupuk KNO3 konsentrasi $3 \%$ (P4), dan pupuk KNO3 konsentrasi 4\% (P5). Apabila hasil dari analisis ragam signifikan, maka pengujian data dilanjutkan dengan Uji Beda Nyata Terkecil (BNT) pada taraf $5 \%$. Hasil penelitian menunjukkan aplikasi $\mathrm{KNO} 3$ berpengaruh nyata terhadap pertumbuhan bibit kelapa sawit pada fase pre-nursery. Pemberian pupuk KNO3 dengan konsentrasi 4\% (P5) menunjukkan hasil pertumbuhan bibit yang lebih optimal dibandingkan dengan perlakuan lainnya pada fase pre-nursery.
\end{abstract}

Kata kunci: Kelapa sawit; Pembibitan; Pupuk KNO3

\begin{abstract}
Fulfillment of quality seeds in the effort of increasing oil palm productivity can be done by means of appropriate fertilization. One of the fertilizers that can be used to optimize seedling growth in the pre-nursery is by using $\mathrm{KNO}_{3}$. The objective of this research was to find out $\mathrm{KNO}_{3}$ concentration in optimizing the growth of oil palm seedlings in the prenursery phase. The research was conducted in the Oil Palm Nursery Unit of Politenik Negeri Lampung. The experimental design used was a single treatment with five replications. The treatments consisted of the recommended compound NPK fertilizer (P1), $1 \%$ concentration of $\mathrm{KNO}_{3}$ fertilizer (P2), $2 \%$ concentration of $\mathrm{KNO} 3$ fertilizer (P3), $3 \%$ concentration of $\mathrm{KNO}_{3}$ fertilizer (P4), and 4\% concentration of $\mathrm{KNO} 3$ fertilizer (P5). Once the results of analysis of variance was significant, the analysis was proceeded with the least significant difference test (LSD) at significance level of $5 \%$. The results showed that the application of $\mathrm{KNO}_{3}$ had a significant effect on the growth of oil palm seedlings in the pre-nursery phase. Application of $\mathrm{KNO}_{3}$ fertilizer with a concentration of $4 \%$ (P5) showed higher growth yields than other treatments in the pre-nursery phase of oil palm seedlings.
\end{abstract}

Keywords: KNO3 Fertilizer; Oil palm; Pre-nursery seed 
Kresna Shifa Usodri \& Bambang Utoyo, Pengaruh Penggunaan $\mathrm{KNO}_{3} \ldots$

\section{PENDAHULUAN}

Tanaman perkebunan kelapa sawit (Elaeis guineensis Jacq.) merupakan komoditas unggulan yang menjadi penyumbang devisa negara terbesar melalui hasil minyak sawit (CPO) dan minyak inti sawit (KPO) jika dibandingkan dengan tanaman perkebunan lainnya seperti kopi, kakao dan karet. Peningkatan luas areal tanam kelapa sawit dari tahun 2017 2019 rata - rata sebesar 300.000 ha per tahunnya (Ditjenbun, 2019). Perkembangan luas areal tersebut akan diikuti dengan bertambahnya permintaan bibit yang bermutu atau berkualitas setiap tahunnya. Karena bibit berkualitas akan menentukan produktivitas dan umur produksi tanaman (Jannah et al., 2012).

Pemenuhan bibit berkualitas dapat dilakukan apabila selama proses pembibitan dilakukan pemeliharaan yang baik dan benar. Tujuan utama dari pembibitan adalah untuk menyediakan bibit yang baik dengan kriteria seragam, sehat, dan kokoh (Burhanuddin et al., 2017). Bibit yang terpelihara akan menghasilkan tanaman yang sehat dan kokoh, sehingga menghasilkan produksi yang optimal. Kegiatan pemeliharaan bibit yang dapat dilakukan adalah dengan memberikan penambahan unsur hara pada proses pertanaman. Kebutuhan unsur hara yang dibutuhkan selama fase vegetatif tanaman adalah unsur hara nitrogen $(\mathrm{N})$. Pemberian unsur hara nitrogen yang tepat dan berimbang dapat merangsang pertumbuhan vegetatif tanaman secara optimal (Shintarika et al., 2015; Mastur, et al., 2015).

Pemupukan yang biasa diberikan adalah pupuk NPK majemuk dan pupuk Kiesserit yang mampu memacu pertumbuhan bibit yang optimal pada pre-nursery maupun main-nursery adalah (Maruli, 2012). Akan tetapi, tingginya biaya pemupukan menyebabkan perlunya alternatif pengganti pupuk dasar untuk mengoptimalkan serapan hara nitrogen (N). Cara yang dapat dilakukan untuk mengoptimalkan pemberian unsur hara nitrogen adalah dengan menggunakan pupuk KNO3.

Unsur $\mathrm{K}$ sangat dibutuhkan, karena dapat meningkatkan serapan $\mathrm{N}$ dan P (Brhane et al., 2017; Du et al., 2017; Zhang et al., 2015). Fauzi \& Susila Putra (2019), juga menyatakan bahwa unsur $\mathrm{K}$ juga dapat meningkatkan penyerapan beberapa unsur hara mikro, salah satunya yakni Mg. Menurut Hutapea et al., (2014), kalium meningkatkan daya tahan tanaman terhadap penyakit, terutama pada bibit yang sangat rentan terhadap serangan penyakit. Kalium sangat berperan dalam memperkuat organ tanaman agar tidak mudah gugur. Pada kondisi kekeringan tanaman akan tetap tumbuh dengan optimal (Hutapea et al., 2014; fauzi dan putra, 2019). Kalium $(\mathrm{K}+)$ bertindak sebagai kofaktor fungsional dalam sintesis protein, permeasi dan keseimbangan ion intraseluler. Namun, proses fisiologisnya tidak dijelaskan secara detail. Oleh karena itu perlu dilakukan penambahan konsentrasi KNO3 pada biji asam jawa untuk mendorong perkecambahan biji asam jawa. (Situmorang et al., 2015).

Nitrogen dan Kalium adalah nutrisi yang paling dibutuhkan dibandingkan dengan unsur lainnya, tanaman membutuhkan unsur tersebut karena nitrogen dan kalium mudah diserap dan dapat digunakan untuk pertumbuhan vegetatif akar, batang dan daun. (Anggraini et al., 2018). Pemberian pupuk KNO3 pada tanaman mampu meningkatkan pertumbuhan dan 
produksi tanaman tembakau varietas deli (Siregar et al., 2018) dan varietas tembakau virginia (Hutapea et al., 2014). Aplikasi KNO3 dalam perlakuan kimiawi juga dapat mengaktifkan kinerja enzim sehingga dapat mematahkan dormansi serta merangsang perkecambahan benih kelapa sawit (Kartika, et al., 2015); dan mempercepat laju pertumbuhan bibit kelapa sawit (D., Elza, and Yosepa 2016) serta pada tanaman aren dan sorgum (Siregar et al., 2016; Anggraini et al., 2018).

Oleh sebab itu, perlu dilakukan pengujian tanaman untuk mengetahui pemberian konsentrasi yang tepat dalam mempercepat laju pertumbuhan bibit tanaman kelapa sawit pada fase prenursery.

\section{BAHAN DAN METODE}

Penelitian dilakukan di lahan pembibitan kelapa sawit Institut Politeknik Negeri Lampung. Alat yang akan digunakan dalam penelitian ini antara lain: meteran, kaliper, SPAD-502 Plus (Konica Minolta, Jepang), CID Bioscience portable laser leaf area meter, timbangan, ember dan gelas ukur. Bahan yang digunakan dalam penelitian ini antara lain: bibit kelapa sawit $D \times P$ varietas Simalungun (PPKS, Medan) umur 1 bulan di persemaian pre- nursery, bambu, plastik lembaran, pupuk NPK majemuk (16:16:16) dan KNO3.

Rancangan percobaan yang digunakan adalah perlakuan tunggal dengan lima ulangan. Perlakuan terdiri dari

P1: pupuk NPK majemuk anjuran,

P2: pupuk KNO3 konsentrasi 1\%,

P3: pupuk KNO3 konsentrasi $2 \%$,

P4: pupuk KNO3 konsentrasi 3\%,

P5: pupuk KNO3 konsentrasi 4\%.

Pemupukan KNO3 dilakukan pada 40 dan 80 hari setelah tanam. Pengamatan dilakukan 100 hari setelah tanam pada parameter tinggi bibit, diameter bibit, jumlah daun, luas daun, dan kehijauan daun. Apabila hasil analisis ragam signifikan maka dilanjutkan dengan uji Beda Nyata Terkecil (BNT) pada taraf $\alpha=5 \%$.

\section{HASIL DAN PEMBAHASAN}

Hasil penelitian menunjukkan bahwa penerapan KNO3 berpengaruh nyata terhadap pertumbuhan dan perkembangan bibit kelapa sawit tahap awal. Seperti yang terlihat dari rangkuman hasil perhitungan untuk masing-masing variabel yang diamati, menunjukkan hasil yang berbeda nyata. Tabel 1 merangkum hasil perhitungan setiap variabel yang diamati.

Tabel 1. Rekapitulasi hasil penelitian pengaruh aplikasi KNO3 pada pertumbuhan bibit kelapa sawit fase pre-nursery.

\begin{tabular}{cc}
\hline Variabel Pengamatan & Signifikasi (Nilai F - Hitung perlakuan) \\
\hline Tinggi Bibit & $71,41^{* *}$ \\
Jumlah Daun & $10,18^{* *}$ \\
Luas Daun & $84,12^{* *}$ \\
Tingkat Kehijauan Daun & $52,66^{* *}$ \\
Diameter Bibit & $40,67^{* *}$ \\
\hline
\end{tabular}

Keterangan : ${ }^{* *}=$ berpengaruh sangat nyata pada taraf $\alpha=5 \%$ 
Hasil tersebut sesuai dengan penelitian (Anggraini et al., 2018) bahwa pemberian $\mathrm{KNO}_{3}$ mampu untuk meningkatkan pertumbuhan kecambah tanaman sorghum. Siregar et al. (2016), menambahkan bahwa pemberian pupuk KNO3 meningkatkan pertumbuhan pada fase vegetatif tanaman. Peningkatan pertumbuhan tersebut disebabkan karena kandungan unsur hara $\mathrm{N}$ dan $\mathrm{K}$ pada pupuk KNO3 yang mampu untuk meningkatkan proses fotosintesis dalam laju metabolisme tanaman.

Karena peningkatan hasil metabolisme nitrogen dan kalium, peningkatan hasil produk fotosintesis akan berdampak pada pertumbuhan tanaman. Pada tahap vegetatif tumbuhan membutuhkan lebih banyak unsur hara nitrogen dan kalium dibandingkan unsur hara lainnya. Hal ini dikarenakan nitrogen dan kalium dapat digunakan dalam waktu yang relatif singkat untuk meningkatkan laju pertumbuhan terutama dalam pembentukan akar, daun dan batang tanaman pada fase vegetatif. (Firmansyah et al., 2017).

Hanafiah (2007), menambahkan bahwa kandungan Nitrogen pada KNO3 juga digunakan untuk merangsang proses pertumbuhan batang, cabang, daun serta pembelahan sel, perkembangan sel dan memperlambat proses pematangan benih (memperpanjang masa vegetatif). Selain itu, senyawa kalium juga sangat berperan dalam pembentukan daun pada tanaman. Oleh sebab itu, pemberian KNO3 mampu meningkatkan pertumbuhan bibit kelapa sawit fase prenursery. Tabel 2 merangkum hasil pengamatan 100 hari setelah tanam, meliputi rerata tinggi bibit, jumlah daun, luas daun, kehijauan daun, dan diameter bibit.

Tabel 2. Rata-rata tinggi, jumlah daun, luas daun, tingkat kehijauan dan diameter bibit kelapa sawit pada fase pra pembibitan (pengamatan 100 hari setelah tanam).

\begin{tabular}{ccccccccccc}
\hline & \multicolumn{10}{c}{ Variabel Pengamatan } \\
\cline { 2 - 12 } Perlakuan & $\begin{array}{c}\text { Tinggi } \\
\text { Bibit (cm) }\end{array}$ & $\begin{array}{c}\text { Jumlah } \\
\text { Daun (helai) }\end{array}$ & $\begin{array}{c}\text { Luas } \\
\text { Daun (cm) }\end{array}$ & $\begin{array}{c}\text { Kehijauan } \\
\text { Daun }\end{array}$ & $\begin{array}{c}\text { Diameter } \\
\text { Bibit (cm) }\end{array}$ \\
\hline P1 & 19.33 & e & 2.67 & c & 157.63 & e & 51.20 & d & 1.00 & d \\
P2 & 21.67 & d & 3.67 & bc & 170.23 & d & 55.60 & c & 1.10 & c \\
P3 & 23.00 & c & 4.33 & bc & 178.03 & c & 58.67 & b & 1.20 & b \\
P4 & 24.67 & b & 5.67 & ab & 195.33 & b & 62.53 & a & 1.27 & b \\
P5 & 26.00 & a & 6.00 & a & 209.97 & a & 63.73 & a & 1.37 & a \\
\hline BNT $\alpha=5 \%$ & 1.00 & & 1.42 & & 7.35 & & 2.31 & 0.07 & \\
\hline
\end{tabular}

Keterangan : Dosis anjuran pupuk NPK majemuk (P1), pupuk KNO3 konsentrasi 1\% (P2), pupuk KNO3 konsentrasi 2\% (P3), pupuk KNO3 konsentrasi 3\% (P4), dan pupuk KNO3 konsentrasi 4\% (P5); Angka yang diikuti huruf yang sama menunjukkan hasil yang tidak berbeda nyata pada uji BNT pada taraf $5 \%$. 
Untuk semua variabel yang diamati, perbedaan konsentrasi pada aplikasi KNO3 menunjukkan hasil yang sangat berbeda. Aplikasi Pupuk KNO3 konsentrasi 4\% (P5) menunjukkan hasil pertumbuhan yang lebih tinggi dari perlakuan lainnya pada bibit kelapa sawit fase pre nursery. Pemberian $\mathrm{KNO} 3$ yang meningkat konsentrasinya pada bibit kelapa sawit pre-nursery menunjukkan laju pertumbuhan yang semakin cepat.

\section{Tinggi Bibit}

Hasil penelitian menunjukkan bahwa penggunaan pupuk $\mathrm{KNO} 3$ dengan konsentrasi 4\% (P5) dapat memberikan pengaruh yang lebih baik pada bibit kelapa sawit dengan tinggi 26 $\mathrm{cm}$. Hal tersebut sesuai dengan penelitian Hutapea et al. (2014), yang menyatakan bahwa pemberian pupuk KNO3 pada tanaman tembakau mampu untuk meningkatkan tinggi tanaman. Pertambahan tinggi bibit yang lebih optimal dibandingkan dengan perlakuan lainnya terutama pupuk Majemuk dikarenakan penyerapan unsur $\mathrm{N}$ dan $\mathrm{K}$ pada KNO3 yang lebih baik. Selain itu, dibandingkan dengan pupuk NPK majemuk, KNO3 mengandung unsur hara nitrogen dan kalium yang lebih tinggi.

Tinggi bibit merupakan hasil pembelahan dan pemanjangan sel. Peningkatan tinggi bibit / tanaman juga disebabkan oleh serapan $\mathrm{N}$ yang meningkat sehingga pertumbuhan tanaman akan optimal. Menurut (Prasetyo, 2014), N memiliki peran dalam pembentukan asam amino yang digunakan untuk pembelahan sel. Adileksana et al. (2020), menambahkan fungsi utama kalium (K) adalah membantu pembentukan protein dan karbohidrat. Selain itu, peran unsur kalium (K) lainnya adalah memperkuat tubuh tumbuhan dan membuat daun, bunga dan buah sulit rontok. Kalium merupakan sumber tenaga tanaman.
Menurut Palupi et al. (2017), Tanaman yang kekurangan $\mathrm{K}$ akan mengalami gangguan dari pengangkutan karbohidrat dari daun ke organ lain. Oleh karena itu pemupukan $\mathrm{KNO} 3$ dan bibit kelapa sawit dengan daya serap yang tinggi, terutama daya serap nitrogen dan kalium yang tinggi, dapat mengoptimalkan pertumbuhan benih kelapa sawit.

$\underline{\text { Jumlah Daun }}$

Hasil penelitian menunjukkan bahwa penggunaan pupuk $\mathrm{KNO} 3$ dengan perlakuan P5 memberikan peningkatan jumlah daun jika dibandingkan dengan perlakuan lainnya. Hasil tersebut sesuai dengan penelitian (Siregar et al. 2018) peningkatan dosis pupuk KNO3 dapat meningkatkan jumlah daun tanaman tembakau varietas deli pada $8 \mathrm{MST}$. Peningkatan tersebut karena serapan $\mathrm{N}$ pada pemupukan KNO3 mampu digunakan secara optimal pada bibit kelapa sawit. Bibit yang kekurangan unsur hara akan sulit membentuk lembaran daun baru, nutrisi yang berperan dalam pembentukan daun salah satunya adalah nitrogen (Adileksana et al., 2020; Prasetyo, 2014).

Secara umum, asupan pemberian pupuk $\mathrm{KNO}_{3}$ mampu untuk meningkatkan pertambahan jumlah daun bibit kelapa sawit. (Duaja, 2012) menyatakan bahwa pemberian pupuk $\mathrm{N}$ akan mampu untuk mensuplai unsur hara yang sangat diperlukan bagi pertumbuhan vegetatif tanaman tertuma tinggi dan jumlah daun. Lebih lanjut Siregar et al. (2018), menyatakan bahwa tingginya kandungan $\mathrm{N}$ dan $\mathrm{K}$ pada pempupukan $\mathrm{KNO}_{3}$ akan mampu untuk mencukupi kebutuhan hara tanaman yang pada akhirnya dapat digunakan untuk pembentukan daun. Oleh sebab itu, peningkatan dosis pemberian KNO3 mampu untuk meningkatkan jumlah daun pada bibit kelapa sawit. Menurut Corley et al. (2016), jumlah daun bibit kelapa sawit akan tumbuh satu daun per 
bulan, sampai bibit berumur enam bulan.

\section{Luas dan Tingkat Kehijauan Daun}

Pemberian Pupuk $\mathrm{KNO}_{3}$ pada tingkat konsentrasi yang berbeda menunjukkan pertambaha luas dan tingkat kehijauan daun yang lebih tinggi jika dibandingkan dengan pupuk NPK Majemuk. Peningkatan konsentrasi pupuk KNO3 mampu untuk meningkatkan luas daun yang pada akhirnya akan mempengaruhi tingkat serapan fotosintesis yang dapat dilihat dari tingkat kehijauan daun bibit kelapa sawit. Hasil tersebut sesuai dengan penelitian Anggraini et al. (2018), dengan meningkatnya dosis $\mathrm{KNO} 3$ maka terjadi peningkatan klorofil daun sorghum yang berkaitan dengan tingkat kehijauan daun; pertambahan dosis KNO3 juga mampu meningkatkan jumlah daun dan luas daun tanaman tembakau deli (Siregar et al., 2018).

Peningkatan tersebut dikarenakan kandungan Nitrogen yang tinggi pada KNO3 mampu untuk meningkatkan pertambahan baik dari segi jumlah maupun luas daun bibit kelapa sawit. Peningkatan pemberian konsentrasi $\mathrm{N}$ pada tanaman akan mampu meningkatkan proses pembentukan protein, asam nukleat dan beberapa substansi lain yang sangat berperan dalam pertumbuhan vegetatif tanaman.

Febrian et al. (2011), menjelaskan bahwa pemberian pupuk $\mathrm{N}$ mampu untuk meningkatkan pertumbuhan vegetatif tanaman. Selain itu, Koten et al. (2012), menyatakan bahwa pemberian unsur $\mathrm{N}$ dan $\mathrm{K}$ yang tinggi pada media tanam akan mampu untuk meningkatkan pigem hijau (Klorofil) pada tanaman. Oleh sebab itu, pemberian pupuk KNO3 pada bibit kelapa sawit mampu meningkatkan pertambahan luas daun dan tingkat kehijauan daun pada tanaman.

Berdasarkan hasil penelitian juga didapatkan bahwa peningkatan luas daun juga mempengaruhi terhadap peningkatan kehijauan daun bibit kelapa sawit. Hasil tersebut sesuai dengan penelitian Setiawati et al. (2016), yang menyatakan bahwa terdapat hubungan peningkatan kehijauan daun atau kadar klorofil daun dengan bertambahnya luas daun. Hal tersebut mengindikasikan bahwa jumlah klorofil tidak hanya dipengaruhi oleh jumlah pigmennya saja, akan tetapi turut dipengaruhi dari besaran luas permukaan daun tanaman (Saiful, 2007). Musyarofah et al. (2006), menambahkan bahwa morfologi daun yang berkaitan dengan ukuran panjang, lebar, dan luasan daun akan mempengaruhi kadar klorofil pada daun. Semakin besar luas permukaan daun maka akan tinggi kandungan klorofil pada daun yang diindikasikan dengan kehijauan pada daun serta begitu pula sebaliknya.

\section{Diameter Batang Bibit}

Peningkatan diameter bibit kelapa sawit lebih optimal dengan pemberian pupuk KNO3 dengan konsentrasi $4 \%$. Hasil tersebut sesuai dengan penelitian Heidari et al. (2014), bahwa pemberian KNO3 dapat meningkatkan diameter tanaman French Tarragon. Hal tersebut membuktikan bahwa pemberian nitrogen dan kalium yang merupakan kandungan utama dalam pupuk $\mathrm{KNO}_{3}$ mampu untuk mempengaruhi laju pertumbuhan yang berkaitan erat dengan fisiologis tanaman.

Ezz El-Din et al. (2010), menyatakan bahwa unsur kalium (K) mampu untuk mensintesis karbohidrat dan berpengaruh positif dalam transportasi air pada tanaman, dan 
pemanjangan sel. Meningkatnya diameter batang tanaman tersebut sangat dipengaruhi oleh kandungan unsur kalium (Hapsoh et al., 2020). Batang berperan sebagai jaringan yang menghubungkan akar dan daun dalam proses penyerapan nutrisi dan penyaluran hasil fotosintesis.

Selain itu, nitrogen juga dapat mempengaruhi pertumbuhan vegetatif dan metabolisme tanaman, serta terlibat langsung atau tidak langsung dalam produksi zat aktif tanaman. Nitrogen dalam ketersediaan yang terus meningkat dan cukup akan mengubah hasil fotosintesis untuk membentuk protoplasma yang dapat mengikat air dan pada akhirnya akan memperbesar pertumbuhan tanaman. Hal inilah yang menyebabkan pertumbuhan vegetatif tanaman meningkat dalam hal diamter bibit kelapa sawit.

\section{KESIMPULAN}

Berdasarkan data hasil penelitian dapat disimpulkan bahwa aplikasi KNO3 dengan konsentrasi 4\% memberikan laju pertumbuhan yang lebih tinggi dan significant jika dibandingkan dengan perlakuan lainnya pada keseluruhan variabel pengamatan.

\section{UCAPAN TERIMAKASIH}

Ucapan terima kasih kami sampaikan kepada Direktur Politeknik Negeri Lampung yang telah memberikan Dana DIPA Politeknik Sehingga terlaksananya penelitian ini dan Ketua Jurusan Budidaya Tanaman Perkebunan yang mensuport penelitian hingga akhir.

\section{DAFTAR PUSTAKA}

Adileksana, C., Yudono, P., Purwanto, B. H., \& Wijoyo, R. B. (2020). The Growth Performance of Oil Palm
Seedlings in Pre-Nursery and Main Nursery Stages as a Response to the Substitution of NPK Compound Fertilizer and Organic Fertilizer. Caraka Tani: Journal of Sustainable Agriculture, $35 \quad$ (1), 89. https://doi.org/10.20961/carakatani. v35i1.33884

Anggraini, P.D., Tundjung, T. H., Yulianty, \& Zulkifli. (2018). The Influence of Giving Compound $\mathrm{KNO}_{3}$ (Potassium Nitrate) Against The Growth of Sorghum (Sorghum bicolor (L.) Moench). Jurnal Biologi Eksperimen Dan Keanekaragaman Hayati, 5(1), 37-42.

Anggraini, Puput Dian, Handayani, T. T., Yulianty, \& Zulkifli. (2018). Pengaruh Pemberian Senyawa $\mathrm{KNO}_{3}$ (Kalium Nitrat) Terhadap Pertumbuhan KEcambah Sorgum (Sorghum bicolor (L.) Moench). Jurnal Biologi Eksperimen Dan KEanekaragaman Hayati, 5(1), 3742.

Brhane, H., Mamo, T., Teka, K., \& Tejada Moral, M. (2017). Optimum potassium fertilization level for growth, yield and nutrient uptake of wheat (Triticum aestivum ) in Vertisols of Northern Ethiopia. Cogent Food \& Agriculture, 3(1), 1347022.

https://doi.org/10.1080/23311932.2

017.1347022

Burhanuddin, Setiawan, H., \& Marlina. (2017). Pengaruh Media Tanam dan Pupuk Daun Terhadap Pertumbuhan Bibit Kelapa Sawit (Elais guineensis Jacq). Agrotropika Hayati, 4(3), 136-151.

Corley, V., R. H., \& Tinker, P. B. (2016). 
The Oil Palm (Fifth Edition) (5th ed.). Willey Blacwell.

D., S., Elza, \& Yosepa, S. (2016). Pematahan Dormansi Benih Kelapa Sawit (Elaeis guineensis Jacq.) Dengan Berbagai Konsentrasi Kalium Nitrat $\left(\mathrm{KNO}_{3}\right)$ Dan Pengaruhnya Terhadap Pertumbuhan Bibit Pada Tahap Pre Nursery. J. JOM Faperta, 4(2), 414.

Ditjenbun. (2019). Statistik Perkebunan Indonesia Komoditas Kelapa Sawit 2017 - 2019. Sekretariat Direktorat Jendral Perkebunan.

Du, Q., Zhao, X., Jiang, C., Wang, X., Han, Y., Wang, J., \& Yu, H. (2017). Effect of Potassium Deficiency on Root Growth and Nutrient Uptake in Maize (Zea mays L.). Agricultural Sciences, 08(11), 1263-1277. https://doi.org/10.4236/as.2017.811 091

Ezz El-Din, A. A., Hendawy, S. F., Eman, E. A., \& Omer, E. . (2010). Enhancing growth, yieldand essential oil of caraway plants by nitrogen and potassium fertilizers. Int. J.Acad. Res, 2(3), 192-197.

Fauzi, W. R., \& Susila Putra, E. T. (2019). Dampak Pemberian Kalium Dan Cekaman Kekeringan Terhadap Serapan Hara Dan Produksi Biomassa Bibit Kelapa Sawit (Elaeis gueenensis Jacq.). Jurnal Penelitian Kelapa Sawit, 27(1), $\quad$ 41-56. https://doi.org/10.22302/iopri.jur.jpk s.v27i1.74

Febrian, I. F., Muryono., M., \& Hendrayana., F. (2011). Pengaruh
Pupuk N. Terhadap Pertumbuhan dan Produksi Tembakau Var. Prancak Pada Kerapatan 36.000/ha di Kabupaten Pamekasan Jawa Timur. Teknologi Sepuluh November.

Hapsoh, H., Dini, I. R., Wawan, W., \& Sianipar, A. H. (2020). The Growth of Oil Palm Seedlings using a Combination Medium of Organic Oil Palm Empty Fruit Bunch and NPK Fertilizer at Main Nursery. Journal of Tropical Soils, 25(2), 61. https://doi.org/10.5400/jts.2020.v25i 2.61-69

Hutapea, A. S., Hadiastono, T., \& Martosudiro, M. (2014). Pengaruh Pemberian Pupuk Kalium $\left(\mathrm{KNO}_{3}\right)$ Terhadap Infeksi Tobacco Mosaik Virus (TMV) pada Beberapa Varietas Tembakau Virginia (Nicotiana tabacum L.). Jurnal HPT, 2(1), 102-109.

I., F., Syakir, M., \& L., L. (2017). The Influence of Dose Combination Fertilizer N, P, and $\mathrm{K}$ on Growth and Yield of Eggplant Crops (Solanum melongena L.)]. Jurnal Hortikultura., 27(1), 69-78.

I., S., \& Widyastuti, Y. E. (1992). Kelapa Sawit Usaha Budidaya, Pemanfaatan Hasil dan Aspek Pemasaran. Penebar Swadaya.

Jannah, N., Fatah, A., \& Marharuddin. (2012). Pengaruh Macam Dan Dosis Pupuk NPK Majemuk Terhadap Pertumbuhan Bibit Kelapa Sawit (Elaeis guineensis Jack). J. Media Sains, 4, 48-54.

Kartika, Surahman, M., \& Susanti, M. (2015). Pematahan Dormansi benih 
Kresna Shifa Usodri \& Bambang Utoyo, Pengaruh Penggunaan $\mathrm{KNO}_{3} \ldots$

kelapa sawit (Elaeis guineensis Jaqc) menggunakan $\mathrm{KNO}_{3}$ dan skarifikasi. Jurnal Pertanian Dan Lingkungan, 8(2), 48-55.

Koten, B. B., Soetrisno, D. R., Ngadiyono, N., \& B., S. (2012). Produksi Tanaman Sorgum (Sorghum bicolor (L.) Moench) Varietas Lokal Rote Sebagai Hijauan Pakan Ruminansia Pada Umur Panen Dan Dosis Pupuk Urea Yang Berbeda. Buletin Peternakan, 36(3), 150-155.

Maruli. (2012). Paduan Lengkap Pengelolaan Kebun dan Pabrik Kelapa Sawit. Agromedia Pustaka.

Mastur, Syafaruddin, \& M.Syakir. (2015). Peran dan Pengelolaan Hara Nitrogen pada Tanaman Tebu Untuk Peningkatan Produktivitas Tebu. Persefektif, 14(2), 72-86.

Palupi, N. E., Aji, T. G., Sari, D. K., \& Sutopo, S. (2017). Efektivitas Dosis dan Aplikasi Pupuk NPK Majemuk Pada Fase Vegetatif Pada Tanaman Strawberry (Fragaria $x$ ananassa Duchesne). AGRISAINTIFIKA: Jurnal IImu-IImu Pertanian, 1(2), 109. https://doi.org/10.32585/ags.v1i2.46

Prasetyo, R. (2014). Pemanfaatan Berbagai Sumber Pupuk Kandang sebagai Sumber N dalam Budidaya Cabai Merah (Capsicum annum L.) di Tanah Berpasir. Planta Tropika: Journal of Agro Science, 2(2), 125132.

https://doi.org/10.18196/pt.2014.03 2.125-132

Shintarika, F., Sudradjat, \& Supijatno. (2015). Optimasi dosis Pupuk
Nitrogen Dan Fosfor Pada Tanaman Kelapa Sawit (Elaeis guineensis Jacq.) Belum Menghasilkan Umur Satu Tahun. Jurnal Agron. Indonesia, 4(3), 250256.

Siregar, M. R., Mukhlis, \& Hilmiyah, Q. (2016). Pengaruh Teknologi Dormansi Secara Fisik Dan Kimia Terhadap Kemampuan Daya Berkecambah Benih Aren (Arenga pinnata). Jurnal Agrohita, 1(1), 5463.

Siregar, R. P., J., G., \& Meriani. (2018). Pertumbuhan dan Produksi Tembakau Deli (Nicotiana tabacum L.) terhadap Pemberian Pupuk KNO3 dan Pupuk Organik Cair Urin Kelinci. Jurnal Agroteknologi FP USU, 6(2), 236-243.

Situmorang, E. M., Riniarti, M., \& Duryat. (2015). Respon Perkecambahan Benih Asam Jawa (Tamarindus indica) Terhadap Berbagai Konsentrasi Larutan Kalium Nitrat $\left(\mathrm{KNO}_{3}\right)$. Jurnal Sylva Lestari, 3(1), 1-8.

Zhang, A. Q., Sechenchogt, Wang, I. H., \& Y. N, W. (2015). Effects of $\mathrm{K}$ Stress On Growth and P Uptake Of Different Genotypes Maize. Hubei Agricultural Sciences, 54, 292-295. 